\title{
Patient reported outcome instruments used in clinical trials of HIV-infected adults on NNRTI- based therapy: a 10-year review
}

Kit N Simpson ${ }^{1}$, Kristin A Hanson ${ }^{2 *}$, Gale Harding ${ }^{3}$, Seema Haider ${ }^{4}$, Margaret Tawadrous ${ }^{4}$, Alexandra Khachatryan ${ }^{5}$, Chris L Pashos ${ }^{6}$ and Albert W Wu ${ }^{7}$

\begin{abstract}
Background: Patient-reported outcomes (PROs) may provide valuable information to clinicians and patients when choosing initial antiretroviral therapy.

Objective: To identify and classify PRO instruments used to measure treatment effects in clinical trials evaluating NNRTIS.

Methods: We conducted a structured literature review using PubMed to identify NNRTI trials published from March 2003 to February 2013. Studies identified--based on disease, instrument, PRO, and NNRTI medication terms were reviewed--to identify PRO instruments. Domains measured within each instrument were recorded to understand key areas of interest in NNRTIs.
\end{abstract}

Results: Of 189 articles reviewed, 27 validated instruments were administered in 26 unique trials, with a mean of 1.9 instruments (median: 1; range: 1-7) per trial. The Medical Outcomes Study HIV Health Survey (MOS-HIV) was the most commonly used instrument ( $n=8$ trials). Seventeen trials (65\%) included at least one multidimensional healthrelated quality of life (HRQL) instrument (HIV-targeted, $n=11$; general, $n=8)$. Other validated instruments measured sleep $(n=5)$, depression $(n=5)$, anxiety $(n=4)$, psychiatric symptoms $(n=2)$, beliefs about HIV medications $(n=2)$, HIV symptoms $(n=1)$, and stress $(n=1)$.

Conclusions: Although review of recent NNRTI trials suggests a lack of consensus on the optimal PRO instruments, a typical battery is comprised of a multidimensional HRQL measure coupled with one or more symptom measures. Further work is needed to clarify advantages and disadvantages of using specific PRO instruments to measure relevant constructs and to identify the most useful batteries of instruments for NNRTI trials.

Keywords: HIV, Patient-reported outcome (PRO), Instrument, NNRTI

\section{Background}

The primary goal of HIV therapy is to increase diseasefree survival and improve health-related quality of life (HRQL) by containing viral replication, avoiding drug resistance, and boosting immunologic function by restoring CD4 count [1,2]. The United States Department of Health and Human Services (DHHS) has recommended several preferred and alternative initial highly active antiretroviral therapy (HAART) regimens which have comparable

\footnotetext{
* Correspondence: kristy.hanson@ubc.com

¿UBC: An Express Scripts Company, 185 Dorval Ave, Suite 500, Dorval, QC H9S 5J9, Canada

Full list of author information is available at the end of the article
}

efficacy, but different pharmacokinetic or pharmacodynamic properties. DHHS further recommends tailoring the HAART regimen to the patient--based on expected side effects, convenience, comorbidities, potential drug interactions, and results of any pre-treatment genotypic drug-resistance testing--to optimize medication adherence and improve long-term treatment success [3]. Since some of these constructs must be measured from the patient perspective, it is important to consider patient-reported outcomes (PROs) when selecting initial antiretroviral therapy.

A PRO is defined as any report of the status of a patient's health condition that comes directly from the patient
C Biomed Central

(c) 2013 Simpson et al.; licensee BioMed Central Ltd. This is an Open Access article distributed under the terms of the Creative Commons Attribution License (http://creativecommons.org/licenses/by/2.0), which permits unrestricted use, distribution, and reproduction in any medium, provided the original work is properly cited. 
without interpretation of the patient's response by a clinician or anyone else [4]. In clinical trials, PRO instruments can be used to measure the effect of a medical intervention on one or more concepts - such as symptoms, functioning, severity of disease, or HRQL. Given the armamentarium of potent HAART regimens available today, HIV infection has been transformed from a terminal illness into a chronic condition. As such, there is a strong case for evaluating the impact of antiretroviral therapies on broader aspects of patient's lives, including psychological health and emotional adjustment. The majority of published comparative treatment studies that include PROs are limited to comparing differences between protease inhibitor (PI) and non-nucleoside reverse transcriptase inhibitor (NNRTI)-based regimens. This may be due in part to the fact that for several years, treatment guidelines have recommended initiating HAART with two NRTIs plus either an NNRTI or a boosted PI [5,6]. However, this broad comparison may miss important distinctions among regimens that are related to within-class PRO differences.

Although five NNRTIs have received Food and Drug Administration (FDA) approval to date, European AIDS Clinical Society (EACS) and DHHS treatment guidelines recommend efavirenz (EFV) as the NNRTI of choice to be used in most treatment-naïve HIV-infected adults initiating NNRTI-based therapy $[3,6]$. Other recommended NNRTIs include nevirapine (NVP) and rilpivirine (RVP). In the absence of head-to-head comparative clinical trials demonstrating clinical superiority of one NNRTI over another, PROs become an important tool for identifying treatment differences and informing treatment choices. A necessary first step to understanding differences among specific NNRTIs is to examine the PRO instruments being used in clinical trials and the aspects of health they measure. Therefore, the purpose of this study was to identify and classify PRO instruments used to measure treatment effects in clinical trials evaluating NNRTIs.

\section{Methods}

\section{Literature search}

An electronic search using PubMed was conducted evaluating studies published from March 2003 to February 2013. Our search strategy included a combination of Medical Subject Headings (MeSH) terms for HIV [HIV OR HIV infections], MeSH terms associated with PROs/instruments [questionnaires OR interviews as topic OR quality of life OR patient satisfaction OR self-evaluation programs], Substance Names of NNRTIs [efavirenz OR nevirapine OR delavirdine OR etravirine OR rilpivirine OR efavirenz, emtricitabine, tenofovir disoproxil fumarate drug combination], and clinical trial Publication Types [clinical trial OR clinical trial, phase IV OR clinical trial, phase III OR clinical trial, phase II OR controlled clinical trial OR randomized controlled trial]. A complete list of all search terms used, including terms used in title/abstract searches, is shown in Additional file 1. We limited our search to articles written in English with abstracts available. In addition to the PubMed search, we conducted a manual search of the bibliographies of the electronicallyidentified primary studies and review articles.

\section{Study selection}

The inclusion and exclusion criteria for studies to be considered in our systematic review were established prior to conducting the literature search. All identified articles were independently screened by two authors. Papers included in our review reported on clinical trials evaluating NNRTI-based treatment regimens in HIVinfected adults and administering at least one validated PRO instrument. Full-text articles of study abstracts which appeared to administer a PRO instrument were reviewed for the name and citation of the validated instrument. Reviews, editorials, animal studies, and those reporting results of children were excluded from our analysis.

\section{Data extraction}

Data collected from each study included population characteristics, study design, study objective, treatments, and PRO instruments administered. We categorized each validated PRO instrument by type (e.g., HRQL, symptoms) to understand key domains of interest in NNRTI-based therapy. We also assessed the number of items, scoring, and dimensions/concepts measured by each instrument. For the most commonly used instruments, PRO-related data (e.g., baseline and follow-up scores, effect sizes, and significance values) were extracted from the studies, as available. The most commonly used PROs and study results were described.

\section{Results}

A total of 189 articles were identified by the literature search and bibliography review. Most articles were excluded because they did not include a validated PRO instrument $(n=111)$. Articles were also excluded for one or more of the following reasons: review articles $(n=33)$, duplicate studies $(n=18)$, evaluated HIV therapies in children $(n=5)$, or did not evaluate NNRTI-based regimens $(\mathrm{n}=13)$. Twenty-six unique clinical trials met all selection criteria and were included in the review.

Table 1 presents the characteristics of the 26 clinical trials. Almost all were randomized controlled trials $(\mathrm{n}=$ 20). The number of PRO instruments per study ranged from 1 to 7 , with most studies including only one (54\%) or two (23\%) validated PRO instruments. In addition to validated PRO instruments, eight of the 26 trials (31\%) used non-validated and study-specific instruments to 
Table 1 Characteristics of included studies

\begin{tabular}{|c|c|c|c|c|c|c|}
\hline Study reference & Population characteristics' & Study design & Objective & Treatment groups & $\begin{array}{l}\text { PRO instruments }{ }^{2} \\
\text { (validated, not } \\
\text { validated) }\end{array}$ & $\begin{array}{l}\text { Types of PRO } \\
\text { instruments } \\
\text { (validated only) }\end{array}$ \\
\hline \multirow[t]{7}{*}{ Dabaghzadeh (2013) [7] } & \multirow{7}{*}{$\begin{array}{l}\text { No prior EFV treatment experience } \\
(\mathrm{n}=51)\end{array}$} & \multirow{7}{*}{$\begin{array}{l}\text { RCT (double-blind, } \\
\text { placebo-controlled) }\end{array}$} & \multirow{7}{*}{$\begin{array}{l}\text { To assess the effect of cyproheptadine } \\
\text { in prevention of neuropsychiatric adverse } \\
\text { adverse drug reactions of ARV regimens } \\
\text { containing EFV }\end{array}$} & \multirow{3}{*}{$\begin{array}{l}\text { 1) ARV therapy } \\
\text { (including EFV) + } \\
\text { cyproheptadine }\end{array}$} & BDI-II & \multirow{2}{*}{$\begin{array}{l}\text { Psychiatric } \\
\text { symptoms (3) }\end{array}$} \\
\hline & & & & & HAM-A & \\
\hline & & & & & HAM-D & Depression (2) \\
\hline & & & & \multirow{4}{*}{$\begin{array}{l}\text { 2) ARV therapy } \\
\text { (including EFV) + } \\
\text { placebo }\end{array}$} & PANSS & Anxiety (1) \\
\hline & & & & & PANSI & Sleep (1) \\
\hline & & & & & PSQI & \\
\hline & & & & & $\begin{array}{l}\text { SCL-90 } \\
\text { somatization } \\
\text { subscale }\end{array}$ & \\
\hline Bucciardini (2012) [8] & $\begin{array}{l}\text { Treatment-experienced patients } \\
\text { with treatment failure, resistance, } \\
\text { or intolerance with HAART ( } 2 \\
\text { NRTIs + NNRTI or PI) }(n=101)\end{array}$ & $\begin{array}{l}\text { Prospective, observational } \\
\text { study (sub-set of ISS-NIA } \\
\text { study) }\end{array}$ & $\begin{array}{l}\text { To evaluate rates and determinants of } \\
\text { virological failure in triple-class experienced } \\
\text { patients receiving raltegravir-based regimens }\end{array}$ & $\begin{array}{l}\text { 1) All patients received } \\
\text { RAL-based therapy; } \\
\text { study compared } \\
\text { patients with and } \\
\text { without virologic failure } \\
\text { on RAL }\end{array}$ & ISSQOL & HRQL: General (1) \\
\hline \multirow[t]{3}{*}{ Lake (2012) [9] } & \multirow{3}{*}{$\begin{array}{l}\text { HIV-infected women with central } \\
\text { adiposity and viral suppression } \\
\text { on NNRTI- or Pl-based HAART } \\
(n=37)\end{array}$} & \multirow[t]{3}{*}{ RCT (open-label) } & \multirow{3}{*}{$\begin{array}{l}\text { To evaluate effects of a switch from a PI or } \\
\text { NNRTI to RAL on adipose tissue volume and } \\
\text { metabolic changes }\end{array}$} & \multirow{2}{*}{$\begin{array}{l}\text { 1) Immediate switch of } \\
\text { PI or NNRTI to RAL } \\
\text { (continuing prior NRTI } \\
\text { backbone) }\end{array}$} & CES-D & Depression (1) \\
\hline & & & & & $\begin{array}{l}\text { Body Image } \\
\text { Impact scale }\end{array}$ & $\begin{array}{l}\text { Psychiatric } \\
\text { symptoms (1) }\end{array}$ \\
\hline & & & & $\begin{array}{l}\text { 2) Delayed switch (at } 24 \\
\text { weeks) of PI or NNRTI to } \\
\text { RAL (continuing prior } \\
\text { NRTI backbone) }\end{array}$ & & \\
\hline \multirow[t]{2}{*}{ Mosam (2012) [10] } & \multirow{2}{*}{$\begin{array}{l}\text { Treatment-naïve patients with } \\
\text { HIV-associated Kaposi sarcoma } \\
(\mathrm{n}=112)\end{array}$} & \multirow[t]{2}{*}{ RCT (open-label) } & \multirow{2}{*}{$\begin{array}{l}\text { To compare HRQL between } 2 \text { ARV regimens: } \\
\text { ZDV/3TC/NFV versus ZDV/3TC/NVP }\end{array}$} & 1) $\mathrm{d} 4 \mathrm{~T} / 3 \mathrm{TC} / \mathrm{NVP}$ & EORTC QLQ-30 & HRQL: General (1) \\
\hline & & & & $\begin{array}{l}\text { 2) } \mathrm{d} 4 \mathrm{~T} / 3 \mathrm{TC} / \mathrm{NVP}+ \\
\text { chemotherapy }\end{array}$ & & \\
\hline \multirow[t]{3}{*}{ Cooper (2011) [11] } & \multirow{3}{*}{$\begin{array}{l}\text { Treatment-experienced patients } \\
\text { on stable ZDV/3TC/EFV regimen } \\
(\mathrm{n}=234)\end{array}$} & \multirow[t]{3}{*}{ RCT (open-label) } & \multirow{3}{*}{$\begin{array}{l}\text { To assess the effect of switching ZDV/3TC/EFV } \\
\text { to TDF/FTC/EFV on adherence, beliefs about } \\
\text { ARV therapy and HQRL }\end{array}$} & \multirow{2}{*}{$\begin{array}{l}\text { 1) Continue ZDV/3TC/ } \\
\text { EFV twice daily }\end{array}$} & BMQ-ART & HRQL: General (1) \\
\hline & & & & & $\begin{array}{l}\text { HAART } \\
\text { Intrusiveness } \\
\text { Scale }\end{array}$ & $\begin{array}{l}\text { Medication beliefs: } \\
\text { HIV-targeted (2) }\end{array}$ \\
\hline & & & & $\begin{array}{l}\text { 2) Switch to TDF/FTC/ } \\
\text { EFV once daily }\end{array}$ & SF-12 (v2) & \\
\hline \multirow[t]{3}{*}{ Nguyen (2011) [12] } & \multirow{3}{*}{$\begin{array}{l}\text { Stable EFV-containing HAART } \\
\text { regimen }(n=53)\end{array}$} & \multirow{3}{*}{$\begin{array}{l}\text { RCT (double-blind, } \\
\text { cross-over) }\end{array}$} & \multirow{3}{*}{$\begin{array}{l}\text { To investigate the effect of replacing EFV with } \\
\text { RAL on patient preference, sleep quality, } \\
\text { daytime sleepiness, anxiety, and lipid levels }\end{array}$} & \multirow{3}{*}{$\begin{array}{l}\text { 1) Continue EFV- } \\
\text { containing regimen, then } \\
\text { switch EFV to RAL } \\
\text { (continuing prior NRTI } \\
\text { backbone) }\end{array}$} & ESS & \multirow[t]{3}{*}{ Sleep (3) } \\
\hline & & & & & GSQS & \\
\hline & & & & & SSS & \\
\hline
\end{tabular}




\begin{tabular}{|c|c|c|c|c|c|c|}
\hline & & & & $\begin{array}{l}\text { 2) RAL + prior NRTI } \\
\text { backbone, then switch }\end{array}$ & $\begin{array}{l}\text { Treatment } \\
\text { preference }\end{array}$ & \\
\hline & & & & $\begin{array}{l}\text { RAL to EFV (continue } \\
\text { prior NRTI backbone) }\end{array}$ & $\begin{array}{l}\text { Treatment } \\
\text { satisfaction }\end{array}$ & \\
\hline \multirow[t]{6}{*}{ Nguyen (2011) [13] } & \multirow{6}{*}{$\begin{array}{l}\text { Stable EFV-containing HAART } \\
\text { regimen }(n=58)\end{array}$} & \multirow{6}{*}{$\begin{array}{l}\text { RCT (double-blind, } \\
\text { cross-over) }\end{array}$} & \multirow{6}{*}{$\begin{array}{l}\text { To investigate the effect of replacing EFV with } \\
\text { ETR on patient preference, sleep, anxiety, and } \\
\text { lipid levels }\end{array}$} & 1) EFV-based therapy & ESS & Sleep (3) \\
\hline & & & & 2) ETR-based therapy & SSS & \multirow{5}{*}{$\begin{array}{l}\text { Anxiety/ } \\
\text { depression/ } \\
\text { stress (1) }\end{array}$} \\
\hline & & & & & GSQS & \\
\hline & & & & & DASS21 & \\
\hline & & & & & $\begin{array}{l}\text { Treatment } \\
\text { preference }\end{array}$ & \\
\hline & & & & & $\begin{array}{l}\text { Treatment } \\
\text { satisfaction }\end{array}$ & \\
\hline \multirow[t]{4}{*}{ Campo (2010) [14] } & \multirow{4}{*}{$\begin{array}{l}\text { PI-based HAART regimen without } \\
\text { history of virological failure } \\
(n=262)\end{array}$} & \multirow{4}{*}{ RCT (open-label) } & \multirow[t]{4}{*}{$\begin{array}{l}\text { To evaluate the efficacy, safety and PROs of } \\
\text { regimen switching to EFV-based HAART }\end{array}$} & $\begin{array}{l}\text { 1) Switch to EFV/3TC/ } \\
\text { ddl }\end{array}$ & $\mathrm{FAHI}$ & HRQL: HIV (1) \\
\hline & & & & \multirow{3}{*}{$\begin{array}{l}\text { 2) Switch PI to EFV } \\
\text { (continuing prior NRTIs) }\end{array}$} & IIRS & \multirow{3}{*}{$\begin{array}{l}\text { HRQL: General } \\
\text { chronic disease (1) }\end{array}$} \\
\hline & & & & & $\begin{array}{l}\text { Treatment } \\
\text { preference }\end{array}$ & \\
\hline & & & & & $\begin{array}{l}\text { Treatment } \\
\text { satisfaction }\end{array}$ & \\
\hline \multirow[t]{2}{*}{ Cella (2010) [15] } & \multirow[t]{2}{*}{$\begin{array}{l}\text { Stable, but virologically failing } \\
\text { ARV regimen }(n=1,203)\end{array}$} & \multirow[t]{2}{*}{$\begin{array}{l}\text { RCT (pooled analysis of } \\
\text { DUET-1 and DUET-2) }\end{array}$} & \multirow[t]{2}{*}{$\begin{array}{l}\text { To study the effects of etravirine versus } \\
\text { placebo on the HRQL of HIV-infected patients }\end{array}$} & $\begin{array}{l}\text { 1) ETR } 200 \text { mg twice- } \\
\text { daily }^{3}\end{array}$ & FAHI & \multirow[t]{2}{*}{ HRQL: HIV (1) } \\
\hline & & & & 2) Placebo $^{3}$ & & \\
\hline \multirow[t]{2}{*}{ Cooper (2010)] [16] } & \multirow[t]{2}{*}{$\begin{array}{l}\text { HIV-infected, treatment-naïve } \\
\text { patients }(n=87)\end{array}$} & \multirow[t]{2}{*}{ RCT (open-label) } & \multirow{2}{*}{$\begin{array}{l}\text { To determine the impact of once-nightly } \\
\text { versus twice-daily dosing and beliefs about } \\
\text { HAART on adherence to EFV-based HAART in } \\
\text { ARV-naïve patients }\end{array}$} & $\begin{array}{l}\text { 1) ddl/3TC/EFV once } \\
\text { nightly }\end{array}$ & BMQ-ART & \multirow[t]{2}{*}{$\begin{array}{l}\text { Medication beliefs } \\
\text { HIV-targeted (2) }\end{array}$} \\
\hline & & & & $\begin{array}{l}\text { 2) AZT/3TC twice daily } \\
+ \text { EFV nightly }\end{array}$ & $\begin{array}{l}\text { HAART } \\
\text { Intrusiveness } \\
\text { Scale }\end{array}$ & \\
\hline \multirow[t]{3}{*}{$\begin{array}{l}\text { Cooper (2010) [17]; } \\
\text { Regnault (2009) [18] }\end{array}$} & \multirow{3}{*}{$\begin{array}{l}\text { HIV-infected treatment-naïve } \\
\text { patients } \\
(\mathrm{n}=895)\end{array}$} & \multirow[t]{3}{*}{$\begin{array}{l}\text { RCT (double-blind) } \\
{[\text { MERIT] }}\end{array}$} & \multirow{3}{*}{$\begin{array}{l}\text { To evaluate the long-term efficacy, safety, } \\
\text { adherence, and HRQL of once-daily EFV- } \\
\text { based HAART }\end{array}$} & $\begin{array}{l}\text { 1) ZDV/3TC + MVC } 300 \\
\text { mg twice daily }\end{array}$ & HIV-SI/SDM & \multirow[t]{3}{*}{ HIV symptoms (1) } \\
\hline & & & & $\begin{array}{l}\text { 2) ZDV/3TC + MVC } 600 \\
\text { mg once daily }\end{array}$ & & \\
\hline & & & & $\begin{array}{l}\text { 3) ZDV/3TC + EFV } 600 \\
\text { mg once daily }\end{array}$ & & \\
\hline \multirow{4}{*}{$\begin{array}{l}\text { Hodder (2010) [19]; } \\
\text { DeJesus (2009) [20] }\end{array}$} & \multirow{4}{*}{$\begin{array}{l}\text { PI- or NNRTI-based ARV regimen } \\
\text { with virologic suppression } \\
(n=300)\end{array}$} & \multirow[t]{4}{*}{ RCT (open-label) } & \multirow{4}{*}{$\begin{array}{l}\text { To evaluate the therapeutic switch to a } \\
\text { single-tablet formulation of EFV/FTC/TDF } \\
\text { among virologically suppressed, HIV-infected } \\
\text { adults }\end{array}$} & 1) EFV/FTC/TDF & SF-36 (V2) & HRQL: General (1) \\
\hline & & & & \multirow{3}{*}{$\begin{array}{l}\text { 2) Continue baseline } \\
\text { ARVs (PI- or NNRTI- } \\
\text { based) }\end{array}$} & HIV-SI/SDM & \multirow[t]{3}{*}{ HIV symptoms (1) } \\
\hline & & & & & $\begin{array}{l}\text { Treatmet } \\
\text { preference }\end{array}$ & \\
\hline & & & & & $\begin{array}{l}\text { Perceived ease of } \\
\text { regimen }\end{array}$ & \\
\hline
\end{tabular}


Table 1 Characteristics of included studies (Continued)

\begin{tabular}{|c|c|c|c|c|c|c|}
\hline \multirow[t]{5}{*}{$\begin{array}{l}\text { Potard (2010) [21] } \\
\end{array}$} & \multirow{5}{*}{$\begin{array}{l}\text { Treatment experienced, NNRTI-na } \\
\text { ive }(n=239)\end{array}$} & \multirow{5}{*}{$\begin{array}{l}\text { Prospective, } \\
\text { observational study }\end{array}$} & \multirow{5}{*}{$\begin{array}{l}\text { To assess changes in HRQL after switching to } \\
\text { an NNRTI-containing regimen }\end{array}$} & 1) EFV-based therapy & HADS & \multirow{2}{*}{$\begin{array}{l}\text { Anxiety/ } \\
\text { depression (1) }\end{array}$} \\
\hline & & & & \multirow[t]{4}{*}{ 2) NVP-based therapy } & HIV-SI/SDM & \\
\hline & & & & & WHOQOL-HIV & HIV symptoms (1) \\
\hline & & & & & BREF & HRQL: General (2) \\
\hline & & & & & SF-12 (v2) & \\
\hline \multirow[t]{4}{*}{ Clifford (2009) [22] } & \multirow{4}{*}{$\begin{array}{l}\text { Treatment-naïv; study reports } \\
\text { long-term follow-up of patients } \\
\text { after unblinding of the AZT/3TC/ } \\
\text { ABC treatment arm }(n=303)\end{array}$} & \multirow{4}{*}{$\begin{array}{l}\text { RCT (secondary analysis } \\
\text { of A5095) }\end{array}$} & \multirow{4}{*}{$\begin{array}{l}\text { To evaluate the long-term impact of EFV- } \\
\text { based regimens on neuropsychological } \\
\text { performance }\end{array}$} & 1) $\mathrm{AZTT} / 3 \mathrm{TC} / \mathrm{EFV}$ & CES-D & Depression (1) \\
\hline & & & & 2) $A Z T / 3 T C / A B C$ & PSQI & Sleep (1) \\
\hline & & & & & STAI & Anxiety (1) \\
\hline & & & & & $\begin{array}{l}\text { Neuropsychiatric } \\
\text { symptoms }\end{array}$ & \\
\hline \multirow[t]{2}{*}{$\begin{array}{l}\text { Gutierrez-Valencia } \\
\text { (2009) [23] }\end{array}$} & \multirow{2}{*}{$\begin{array}{l}\text { Patients scheduled to receive an } \\
\text { EFV-containing treatment plus } 2 \\
\text { NRTIs }(n=114)\end{array}$} & \multirow[t]{2}{*}{ RCT (double-blind) } & \multirow{2}{*}{$\begin{array}{l}\text { To determine if starting EFV in a stepwise } \\
\text { dose schedule decreases EFV-related } \\
\text { neuropsychiatric adverse events while } \\
\text { maintaining efficacy }\end{array}$} & $\begin{array}{l}\text { 1) EFV-based therapy } \\
\text { (stepwise dosing) }\end{array}$ & OSQ & \multirow[t]{2}{*}{ Sleep (1) } \\
\hline & & & & $\begin{array}{l}\text { 2) EFV-based therapy } \\
\text { (full dose) }\end{array}$ & $\begin{array}{l}\text { Neuropsychiatric } \\
\text { symptoms }\end{array}$ & \\
\hline Jayaweera (2009 ) [24] & $\begin{array}{l}\text { Treatment-experienced patients } \\
(n=65)\end{array}$ & $\begin{array}{l}\text { Prospective, single-arm } \\
\text { trial (open-label) } \\
\text { [DART I] }\end{array}$ & $\begin{array}{l}\text { To evaluate the long-term efficacy, safety, } \\
\text { adherence, and HRQL of once-daily EFV- } \\
\text { based HAART }\end{array}$ & $\begin{array}{l}\text { 1) ddl/3TC/EFV once- } \\
\text { daily }\end{array}$ & MOS-HIV & HRQL: HIV (1) \\
\hline Jayaweera (2009) [24] & $\begin{array}{l}\text { Treatment-experienced patients } \\
(n=70)\end{array}$ & $\begin{array}{l}\text { Prospective, single-arm } \\
\text { trial (open-label) } \\
\text { [DART II] }\end{array}$ & $\begin{array}{l}\text { To evaluate the long-term efficacy, safety, } \\
\text { adherence, and HRQL of once-daily EFV- } \\
\text { based HAART }\end{array}$ & $\begin{array}{l}\text { 1) d4T/3TC/EFV once- } \\
\text { daily }\end{array}$ & MOS-HIV & HRQL: HIV (1) \\
\hline \multirow[t]{4}{*}{ Boyle (2008) [25] } & \multirow{4}{*}{$\begin{array}{l}\text { Treatment-experienced patients } \\
\text { on stable twice-daily or more } \\
\text { frequent HAART ( } n=320 \text { ) }\end{array}$} & \multirow[t]{4}{*}{ RCT (open-label) } & \multirow{4}{*}{$\begin{array}{l}\text { To evaluate the effect of regimen } \\
\text { simplification on maintenance of virologic } \\
\text { suppression and treatment adherence }\end{array}$} & \multirow{2}{*}{$\begin{array}{l}\text { 1) Continue baseline } \\
\text { ARVs (BID + dosing) }\end{array}$} & $\mathrm{FAHI}$ & HRQL: HIV (1) \\
\hline & & & & & IIRS & \multirow[t]{3}{*}{ HRQL: General (1) } \\
\hline & & & & $\begin{array}{l}\text { 2) Switch to once-daily } \\
\text { d4T/3TC/EFV }\end{array}$ & $\begin{array}{l}\text { Treatment } \\
\text { preference }\end{array}$ & \\
\hline & & & & & $\begin{array}{l}\text { Treatment } \\
\text { satisfaction }\end{array}$ & \\
\hline \multirow[t]{3}{*}{ DeJesus (2008) [26] } & \multirow{3}{*}{$\begin{array}{l}\text { Stable regimen of fixed-dose } \\
\text { AZT/3TC with EFV, experiencing } \\
\text { AZT/3TC-related adverse effects } \\
\text { or who might benefit from a } \\
\text { simplified regimen }(n=402)\end{array}$} & \multirow{3}{*}{$\begin{array}{l}\text { Prospective, single-arm } \\
\text { trial }\end{array}$} & \multirow{3}{*}{$\begin{array}{l}\text { To evaluate the impact of switching from } \\
\text { twice-daily AZT/3TC to once-daily TDF/FTC } \\
\text { with EFV) }\end{array}$} & \multirow{3}{*}{$\begin{array}{l}\text { 1) Switch from twice- } \\
\text { daily AZT/3TC to once- } \\
\text { daily TDF/FTC with EFV }\end{array}$} & SF-36 (v2) & HRQL: General (1) \\
\hline & & & & & HIV-SI/SDM & HIV symptoms (1) \\
\hline & & & & & $\begin{array}{l}\text { Treatment } \\
\text { satisfaction }\end{array}$ & \\
\hline \multirow[t]{3}{*}{ Bucciardini (2007) [27] } & \multirow[t]{3}{*}{ Treatment-naïve $(n=139)$} & \multirow{3}{*}{$\begin{array}{l}\text { RCT (secondary analysis } \\
\text { of INITIO-QoL data) }\end{array}$} & \multirow{3}{*}{$\begin{array}{l}\text { To detect differences in patient's HRQL } \\
\text { among the } 3 \text { study treatment groups in the } \\
\text { INITIO trial }\end{array}$} & 1) $\mathrm{ddl} / \mathrm{d} 4 \mathrm{~T} / \mathrm{EFV}$ & MOS-HIV & \multirow[t]{3}{*}{ HRQL: HIV (1) } \\
\hline & & & & 2) $\mathrm{ddl} / \mathrm{d} 4 \mathrm{~T} / \mathrm{NFV}$ & & \\
\hline & & & & 3) $\mathrm{ddl} / \mathrm{d} 4 \mathrm{~T} / \mathrm{EFV} / \mathrm{NFV}$ & & \\
\hline \multirow[t]{2}{*}{ Lafaurie (2008) [28] } & \multirow[t]{2}{*}{$\begin{array}{l}\text { NNRTI-naïve, receiving stable } \\
\text { HAART consisting of at least } 1 \text { PI, } \\
1 \text { NRTI and AZT }(n=158)\end{array}$} & $\begin{array}{l}\text { RCT (open-label; } \\
\text { secondary analysis of } \\
\text { ALIZE data) }\end{array}$ & $\begin{array}{l}\text { To assess if patients who have tolerated long- } \\
\text { term AZT regimens will benefit from a switch } \\
\text { to EFV/ddl/FTC }\end{array}$ & $\begin{array}{l}\text { 1) Maintenance of } \\
\text { stable Pl-containing } \\
\text { regimen }\end{array}$ & MOS-HIV & HRQL: HIV (1) \\
\hline & & & & $\begin{array}{l}\text { 2) Switch to once-daily } \\
\text { EFV/ddl/FTC }\end{array}$ & & \\
\hline
\end{tabular}
dherence, and HRQL of once-daily EFVbased HAAR

simplification on maintenance of virologic suppression and treatment adherence

EFV/ddl/FTC 
Table 1 Characteristics of included studies (Continued)

\begin{tabular}{|c|c|c|c|c|c|c|}
\hline \multirow[t]{2}{*}{ Journot (2006) [29] } & \multirow{2}{*}{$\begin{array}{l}\text { NNRTI-naïve, receiving } \\
\text { unchanged HAART for } \geq 6 \\
\text { months consisting of at least } 1 \text { PI } \\
\text { and } 2 \text { NRTIs }(n=355)\end{array}$} & \multirow{2}{*}{$\begin{array}{l}\text { RCT (open-label; } \\
\text { secondary analysis of } \\
\text { ALIZE data) }\end{array}$} & \multirow{2}{*}{$\begin{array}{l}\text { To determine whether EFV use is associated } \\
\text { with a higher incidence of depressive } \\
\text { disorders compared to Pl-containing } \\
\text { regimens }\end{array}$} & $\begin{array}{l}\text { 1) Continue Pl-based } \\
\text { therapy }\end{array}$ & \multirow[t]{2}{*}{ CES-D } & \multirow[t]{2}{*}{ Depression (1) } \\
\hline & & & & $\begin{array}{l}\text { 2) Switch to EFV-based } \\
\text { therapy }\end{array}$ & & \\
\hline \multirow[t]{2}{*}{$\begin{array}{l}\text { Portsmouth (2005) } \\
\text { [30] }\end{array}$} & \multirow{2}{*}{$\begin{array}{l}\text { Treatment-experienced patients } \\
\text { with virologic suppression } \\
\text { receiving d4T/3TC/EFV or ZDV/ } \\
\text { 3TC/EFV }(n=43)\end{array}$} & \multirow[t]{2}{*}{ RCT (open-label) } & \multirow{2}{*}{$\begin{array}{l}\text { To assess whether virologically controlled HIV- } \\
\text { 1-infected individuals switched from a twice- } \\
\text { daily antiretroviral regimen to a once-daily } \\
\text { regimen demonstrate improved adherence } \\
\text { and quality of life while maintaining } \\
\text { virological control }\end{array}$} & $\begin{array}{l}\text { 1) Continue twice-daily } \\
\text { regimen of d4T(IR)/3TC/ } \\
\text { EFV or ZDV/3TC/EFV }\end{array}$ & \multirow[t]{2}{*}{ MOS-HIV } & \multirow[t]{2}{*}{ HRQL: HIV (1) } \\
\hline & & & & $\begin{array}{l}\text { 2) Switch to once-daily } \\
\text { d4T(PRC)/3TC/EFV }\end{array}$ & & \\
\hline \multirow[t]{2}{*}{ Casado (2004) [31] } & \multirow{2}{*}{$\begin{array}{l}\text { Treatment-naïve; subset of } \\
\text { patients with HRQL data in } \\
\text { original COMBINE trial } \\
(n=127)\end{array}$} & \multirow{2}{*}{$\begin{array}{l}\text { RCT (secondary analysis } \\
\text { of COMBINE) }\end{array}$} & \multirow{2}{*}{$\begin{array}{l}\text { To compare HRQL between } 2 \text { ARV regimens: } \\
\text { ZDV/3TC/NFV versus ZDV/3TC/NVP }\end{array}$} & 1) ZDV/3TC/NFV & \multirow[t]{2}{*}{ MOS-HIV } & \multirow[t]{2}{*}{ HRQL: HIV (1) } \\
\hline & & & & 2) $Z \mathrm{DV} / 3 \mathrm{TC} / \mathrm{NVP}$ & & \\
\hline \multirow[t]{2}{*}{ Negredo (2004) [32] } & \multirow[t]{2}{*}{$\begin{array}{l}\text { HAART experienced patients with } \\
\text { long-lasting viral suppression } \\
(\mathrm{n}=169)\end{array}$} & \multirow[t]{2}{*}{$\begin{array}{l}\text { Prospective, } \\
\text { observational study }\end{array}$} & \multirow{2}{*}{$\begin{array}{l}\text { To explore the long-term safety, and the } \\
\text { virological and immunological efficacy of } \\
\text { once-daily ddl/TDF/NVP in previously HAART- } \\
\text { experienced subjects with long-lasting viral } \\
\text { suppression }\end{array}$} & $\begin{array}{l}\text { 1) Continue twice-daily } \\
\text { ARV therapy (PI- or } \\
\text { NNRTI-based) }\end{array}$ & \multirow[t]{2}{*}{ MOS-HIV } & \multirow[t]{2}{*}{ HRQL: HIV (1) } \\
\hline & & & & $\begin{array}{l}\text { 2) Switch to once-daily } \\
\text { ddl/TDF/NVP }\end{array}$ & & \\
\hline \multirow[t]{3}{*}{ van Leth (2004) [33] } & \multirow{3}{*}{$\begin{array}{l}\text { Treatment-naïve; subset of } \\
\text { patients with HRQL data in } \\
\text { original 2NN clinical trial } \\
(n=917)\end{array}$} & \multirow{3}{*}{$\begin{array}{l}\mathrm{RCT} \text { (secondary analysis } \\
\text { of } 2 \mathrm{NN} \text { data) }\end{array}$} & \multirow{3}{*}{$\begin{array}{l}\text { To investigate whether these differences in } \\
\text { the safety profiles of EFV and NVP translates } \\
\text { into differences in HRQL }\end{array}$} & 1) $\mathrm{d} 4 \mathrm{~T} / 3 \mathrm{TC} / \mathrm{EFV}$ & \multirow[t]{3}{*}{ MOS-HIV } & \multirow[t]{3}{*}{ HRQL: HIV (1) } \\
\hline & & & & 2) $\mathrm{d} 4 \mathrm{~T} / 3 \mathrm{TC} / \mathrm{NVP}$ & & \\
\hline & & & & 3) $\mathrm{d} 4 \mathrm{~T} / 3 \mathrm{TC} / \mathrm{EFV} / \mathrm{NVP}$ & & \\
\hline \multicolumn{7}{|c|}{$\begin{array}{l}\text { Abbreviations: } 3 \text { TC lamivudine, ABC abacavir, ACTG AIDS Clinical Trials Group, ARV antiretroviral, AZT zidovudine, BDI-II Beck Depression Inventory, second edition, BMQ-ART Beliefs about Medicines Questionnaire, } \\
\text { adapted for antiretroviral therapy, CES-D Centre for Epidemiologic Studies-Depression scale, d4T stavudine, DASS21 Depression Anxiety and Stress Scale-short version, ddl didanosine, EFV efavirenz, EORTC QLQ-30 } \\
\text { European Organization for Research and Treatment of Cancer Quality of Lfe Questionnaire, ESS Epworth Sleep Score, ETR etravirine, FAHI Functional Assessment of HIV Infection, FTC emtricitabine, GSQS Groningen } \\
\text { Sleep Quality Score, HAART highly-active antiretroviral therapy, HADS Hospital Anxiety and Depression Scale, HAM-A Hamilton Anxiety Rating Scale, HAM-D Hamilton Depression Rating Scale, HIV-SI HIV Symptom } \\
\text { Index, HRQL health-related quality of life, IIRS IIlness Intrusiveness Rating Scale, ISSQoL Istituto Superiore di Sanità Quality of Life, MOS-HIV Medical Outcomes Study HIV health survey, NFV nelfinavir, NNRTI non- } \\
\text { nucleoside reverse transcriptase inhibitor, NRTI nucleoside/nucleotide reverse transcriptase inhibitor, NVP nevirapine, PANSI Positive and Negative Syndrome Scale, PANSS Positive and Negative Suicide Ideation, PI } \\
\text { protease inhibitor, PRO patient-reported outcome, PSQI Pittsburgh Sleep Quality Index, RCT randomized controlled trial, SCL-90 Symptom Checklist-90, SDM Symptom Distress Module, SF-12 MOS } 12 \text {-item short-form } \\
\text { health survey, SF-36 MOS } 36 \text {-item short-form health survey, SSS Stanford Sleepiness Scale, STAI State-Trait Anxiety Inventory, TDF tenofovir, WHOQOL-HIV BREF World Health Organization Quality of Life-HIV, } \\
\text { short version. }\end{array}$} \\
\hline
\end{tabular}

optimized background regimen of at least 2 ARVs consisting of NRTI(s). 
measure such aspects as treatment preference, treatment satisfaction, perceived ease of regimen, and neuropsychiatric symptoms.

The PRO instruments used corresponded to each study's primary objective (e.g., HRQL studies used general or HIVtargeted HRQL instruments, a study to compare depressive symptoms in patients taking EFV- versus PI-based regimens used the CES-D, a depression-specific PRO instrument, etc.). Most studies utilizing a generic HRQL instrument (e.g., SF-36, SF-12) also included either an HIVtargeted HRQL or symptom instrument [11,14,19-21,25].

Overall, 27 validated PRO instruments were identified. Six of the instruments the Medical Outcomes Study HIV Health Survey (MOS-HIV), Functional Assessment of HIV Infection (FAHI), World Health Organization Quality of Life HIV BREF (WHOQOL-HIV BREF), HIV Symptom Index (HIV-SI)/AIDS Clinical Trials Group Symptom Distress Module (SDM), Beliefs about Medicines Questionnaire-ART version (BMQ-ART) and HAART Intrusiveness Scale were developed specifically to be administered in the HIV population. The remaining instruments were either generic HRQL instruments or general symptom-specific instruments.

Characteristics of the PRO instruments, including the number of items, concepts measured, and scoring method, are presented in Table 2. Based on review of the concepts measured by the PROs, key areas of interest measured by PROs in NNRTI clinical trials include general and HIVtargeted HRQL (typically comprised of physical, emotional, social, and functioning domains), HIV-related symptoms (including anxiety, depression, sleep, psychiatric symptoms, and stress), and medication-related beliefs.

Table 3 provides a summary of the validated PRO instruments, categorized by instrument type, utilized in the 26 studies. The MOS-HIV, administered in 8 clinical trials, was the most commonly used PRO instrument. Table 4 presents PRO results for all PRO instruments used in three or more studies: the MOS-HIV, FAHI, HIV-SI/SDM, and CES-D.

\section{Discussion}

Evaluation of PROs during clinical practice, as well as in clinical research, enhances understanding of disease impact and effect of treatment on that disease impact. Thus, PRO assessment should be recognized by patients and their physicians, as well as by payers and health technology assessment authorities, as improving the knowledge base on which to base health care decision making, and ultimately to improve patient health. This study found that the key areas of PRO interest in clinical trials of NNRTI-based therapy are HRQL (general or HIV-targeted, and typically comprised of physical, emotional, social and functioning domains), HIV symptoms, sleep, and psychiatric symptoms, including anxiety, depression, stress, and medication beliefs. A variety of instruments were used to measure these dimensions. The only instruments used in three or more clinical trials within the past ten years were the MOS-HIV, FAHI, and CES-D.

Overall, although we were able to identify important concepts measured in NNRTI studies based on the convergence of PRO instrument types (e.g., HRQL, HIV symptoms, anxiety, depression), there was a noticeable lack of consensus among studies on specific instruments utilized to measure each concept. For example, of five generic HRQL instruments identified, none were used in more than two studies.

To our knowledge, this is the first study to systematically identify and categorize PRO instruments used specifically in NNRTI clinical trials. Clinical trials commonly use more than one PRO instrument. Although each PRO instrument may be able to contribute valuable information, it is important to carefully weigh the advantages and disadvantages of each instrument, especially related to its sensitivity and specificity to capture the patient factors of greatest importance. This is important both maximize the chances of detecting important differences between treatments, as well as to limit patient response burden.

A multidimensional generic HRQL instrument, such as the SF-36 or EQ-5D, is useful because it comprehensively measures HRQL and has norm-based scoring which can be used to compare the study population with others. Furthermore, it can be used in population-wide decision making by providing data on quality of life weights or utilities for inclusion in cost-effectiveness and cost-utility analyses. For example, this can be done directly (e.g., using the EQ5D) or indirectly (e.g., by deriving SF-6D utility weights from the SF-36). However, a disadvantage of using generic measures is that they may be less sensitive or responsive to small but important changes that occur due to changes in disease status, adverse events, or to treatment effect, and which may occur over the typical timeframe of a randomized control trial.

HIV-targeted HRQL instruments, such as the MOSHIV, FAHI, and WHOQOL-HIV BREF, were each developed by revising, at least in part, generic HRQL instruments (the SF-20, Functional Assessment of Cancer Therapy-General [FACT-G], and WHOQOL-BREF, respectively) with input from HIV-infected patients and HIV-treatment providers to ensure more complete coverage of concepts specific to HIV infection. Each instrument demonstrates excellent psychometric properties in the HIV population. In contrast to the generic HRQL instruments, a disadvantage of HIV-targeted instruments is that they do not provide a means for estimating utilities, which can be useful in clinicaleconomic modeling considered by health technology assessment authorities and others focused on population health. 
Table 2 Characteristics of identified PRO measures

\begin{tabular}{|c|c|c|c|c|c|c|}
\hline \multirow[t]{2}{*}{ Name } & \multirow{2}{*}{$\begin{array}{l}\text { Instrument } \\
\text { type }\end{array}$} & \multirow{2}{*}{$\begin{array}{l}\text { Items } \\
(\mathrm{N})\end{array}$} & \multirow[t]{2}{*}{ Domains/scales/concepts } & \multicolumn{3}{|c|}{ Score type(s) } \\
\hline & & & & Dimension & Summary ${ }^{1}$ & Total \\
\hline BDI-II & $\begin{array}{l}\text { Psychiatric } \\
\text { symptoms }^{2}\end{array}$ & 21 & Severity of depression & & & $x$ \\
\hline BMQ-ART & $\begin{array}{l}\text { Medication } \\
\text { beliefs (HIV- } \\
\text { targeted) }\end{array}$ & 19 & $\begin{array}{l}\text { HAART necessity scale (beliefs about personal need for HAART for } \\
\text { controlling HIV, maintaining their health, preventing illness), HAART } \\
\text { concerns scale (potential adverse effects, dependence, embarrassment } \\
\text { about treatment, etc.) }\end{array}$ & $x$ & & \\
\hline $\begin{array}{l}\text { Body Image } \\
\text { Impact }\end{array}$ & $\begin{array}{l}\text { Psychiatric } \\
\text { symptoms }\end{array}$ & 3 & Belly size, belly image distress, belly profile & $x$ & & \\
\hline CES-D & $\begin{array}{l}\text { Psychiatric } \\
\text { symptoms }^{2}\end{array}$ & 20 & Frequency and severity of depression symptoms & & & $X$ \\
\hline DASS21 & $\begin{array}{l}\text { Psychiatric } \\
\text { symptoms }\end{array}$ & 21 & Depression, anxiety, stress & $x$ & & \\
\hline $\begin{array}{l}\text { EORTC QLQ- } \\
30\end{array}$ & HRQL (general) & 30 & $\begin{array}{l}6 \text { functioning scales (physical, role, cognitive, emotional, social, global } \\
\text { QOL), } 9 \text { symptom scales/items (fatigue, pain, nausea and vomiting, } \\
\text { dyspnea, sleep disturbance, appetite loss, constipation, diarrhea, financial } \\
\text { impact) }\end{array}$ & $x$ & & \\
\hline ESS & Sleep $^{5}$ & 8 & Rates chances of dozing during the daytime in 8 situations & & & $X$ \\
\hline $\mathrm{FAHI}$ & $\begin{array}{l}\mathrm{HRQL}(\mathrm{HIV}- \\
\text { targeted) }\end{array}$ & 47 & $\begin{array}{l}\text { Physical well-being, functional and global well-being, emotional well- } \\
\text { being/living with HIV, social well-being, cognitive functioning }\end{array}$ & $x$ & & $X$ \\
\hline GSQS & Sleep ${ }^{6}$ & 15 & Questions about quality of previous night's sleep & & & $X$ \\
\hline $\begin{array}{l}\text { HAART } \\
\text { Intrusiveness } \\
\text { Scale }\end{array}$ & $\begin{array}{l}\text { Medication } \\
\text { beliefs (HIV- } \\
\text { targeted) }\end{array}$ & 12 & $\begin{array}{l}\text { Degree to which ART is perceived to interfere with aspects of daily life } \\
\text { (e.g., social life, ability to work, relationships) }\end{array}$ & & & $X$ \\
\hline HADS & $\begin{array}{l}\text { Psychiatric } \\
\text { symptoms }^{2,3}\end{array}$ & 14 & Anxiety, depression & $x$ & & \\
\hline HAM-A & $\begin{array}{l}\text { Psychiatric } \\
\text { symptoms }^{3}\end{array}$ & 14 & Severity of anxiety & & & $X$ \\
\hline HAM-D & $\begin{array}{l}\text { Psychiatric } \\
\text { symptoms }^{2}\end{array}$ & 17 & Severity of depression & & & $x$ \\
\hline HIV-SI / SDM & HIV symptoms & 20 & $\begin{array}{l}\text { HIV- or treatment-related symptoms (e.g., fatigue, dizziness, nausea, } \\
\text { depression, anxiety) }\end{array}$ & & $X^{7}$ & $x$ \\
\hline IIRS & HRQL (general) & 13 & Relationships and personal development, intimacy, instrumental & $x$ & & $x$ \\
\hline ISSQOL & $\begin{array}{l}\text { HRQL }(\mathrm{HIV}- \\
\text { targeted) }\end{array}$ & 62 & $\begin{array}{l}\mathrm{QOL} \text { core (satisfaction with QOL, physical well-being, role well-being, } \\
\text { social functioning, depression/anxiety, energy/vitality, health distress, } \\
\text { cognitive functioning, sexual life), Additional important areas (social } \\
\text { support, interaction with medical staff, treatment impact, body changes, } \\
\text { life planning, motherhood/fatherhood) }\end{array}$ & $x$ & & \\
\hline MOS-HIV & $\begin{array}{l}\text { HRQL (HIV- } \\
\text { targeted) }\end{array}$ & 35 & $\begin{array}{l}\text { General health perceptions, physical functioning, role functioning, social } \\
\text { functioning, pain, energy/fatigue, health distress, mental health, cognitive } \\
\text { functioning, and quality of life }\end{array}$ & $x$ & $x^{1}$ & $x$ \\
\hline OSQ & Sleep $^{6}$ & 13 & Subjective sleep quality, somnolence, insomnia, nightmares & & & $x$ \\
\hline PANSI & $\begin{array}{l}\text { Psychiatric } \\
\text { symptoms }\end{array}$ & 14 & Positive suicidal ideation, negative suicidal ideation & $x$ & & \\
\hline PANSS & $\begin{array}{l}\text { Psychiatric } \\
\text { symptoms }\end{array}$ & 30 & $\begin{array}{l}\text { Positive items (e.g., delusions, hallucinations), Negative items (e.g., } \\
\text { blunted affect, emotional withdrawal), General Psychopathology (e.g., } \\
\text { anxiety, depression, disorientation) }\end{array}$ & $x$ & & $x$ \\
\hline PSQI & Sleep ${ }^{6}$ & 19 & $\begin{array}{l}\text { Subjective sleep quality, sleep latency, sleep duration, habitual sleep efficiency, } \\
\text { sleep disturbances, use of sleeping medication, daytime dysfunction }\end{array}$ & & & $X$ \\
\hline $\begin{array}{l}\text { SCL-90 } \\
\text { Somatization } \\
\text { subscale }\end{array}$ & $\begin{array}{l}\text { Psychiatric } \\
\text { symptoms }\end{array}$ & 12 & $\begin{array}{l}\text { Distress arising from perceptions of bodily dysfunction, such as } \\
\text { cardiovascular, gastrointestinal, respiratory, and autonomic symptoms }\end{array}$ & $x$ & & \\
\hline SF-12 & HRQL (general) & 12 & $\begin{array}{l}\text { Physical functioning, role physical, bodily pain, general health, vitality, } \\
\text { social functioning, role emotional, mental health }\end{array}$ & $x$ & $X^{1}$ & \\
\hline
\end{tabular}


Table 2 Characteristics of identified PRO measures (Continued)

\begin{tabular}{|c|c|c|c|c|c|}
\hline SF-36 & HRQL (general) & 36 & $\begin{array}{l}\text { Physical functioning, role-physical, bodily pain, general health, vitality, } \\
\text { social functioning, role-emotional, mental health, reported health } \\
\text { transition }\end{array}$ & $x$ & $X^{1}$ \\
\hline SSS & Sleep $^{5}$ & 1 & $\begin{array}{l}\text { Subjects select } 1 \text { statement to best describe typical sleepiness at work } \\
\text { during the prior week }\end{array}$ & & $x$ \\
\hline STAI & $\begin{array}{l}\text { Psychiatric } \\
\text { symptoms }^{3}\end{array}$ & 40 & State anxiety, trait anxiety & & $x$ \\
\hline $\begin{array}{l}\text { WHOQOL-HIV } \\
\text { BREF }\end{array}$ & $\begin{array}{l}\text { HRQL }(\mathrm{HIV}- \\
\text { targeted) }\end{array}$ & 31 & $\begin{array}{l}\text { Physical, psychological, level of independence, social relationships, } \\
\text { environment, spirituality }\end{array}$ & $x$ & \\
\hline \multicolumn{6}{|c|}{$\begin{array}{l}\text { Abbreviations: BDI-II Beck Depression Inventory, second edition, BMQ-ART Beliefs about Medicines Questionnaire, adapted for antiretroviral therapy, CES-D Centers } \\
\text { for Epidemiological Studies-Depression, DASS21 Depression Anxiety and Stress Scale, short version, EORTC QLQ-30 European Organization for Research and } \\
\text { Treatment of Cancer Quality of Life Questionnaire, ESS Epworth Sleep Score, FAHI Functional Assessment of HIV Infection, GSQS Groningen Sleep Quality Score, } \\
\text { HAART Highly Active Antiretroviral Therapy, HADS Hospital Anxiety and Depression Scale, HAM-A Hamilton Anxiety Rating Scale, HAM-D Hamilton Depression } \\
\text { Rating Scale, HIV-SI HIV Symptom Index, HRQL health-related quality of life, IIRS Illness Intrusiveness Rating Scale, ISSQoL Istituto Superiore di Sanità Quality of Life, } \\
\text { MOS-HIV Medical Outcomes Study-HIV, OSQ Oviedo Sleep Questionnaire, PANSI Positive and Negative Syndrome Scale, PANSS Positive and Negative Suicide } \\
\text { Ideation, PSQI Pittsburgh Sleep Quality Index, SCL-90 Symptom Checklist-90, SDM Symptom Distress Module, SF-12 MOS } 12 \text {-item short-form health survey, SF-36 } \\
\text { MOS 36-item short-form health survey, SSS Stanford Sleepiness Scale, STAI State-Trait Anxiety Index, WHOQOL-HIV BREF World Health Organization Quality of } \\
\text { Life-HIV, short version. } \\
{ }^{1} \text { Physical health and mental health summary scores; }{ }^{2} \text { Depression; }{ }^{3} \text { Anxiety; }{ }^{4} \text { Stress; }{ }^{5} \text { Daytime sleepiness; }{ }^{6} \text { Sleep quality; }{ }^{7} \text { Symptom count and symptom } \\
\text { bother count. }\end{array}$} \\
\hline
\end{tabular}

For HIV-related symptoms, the HIV-SI/SDM is considered to be the gold standard in clinical research. However, a generic symptom-specific instrument may be more appropriate when the primary or secondary study objective is to measure a specific symptom; such symptom-specific instruments generally measure the symptom and different attributes and impacts with multiple items, thus providing greater insights into the extent and effect of the measure.

More than half of the articles initially identified were excluded from our review because the abstract did not report use of a PRO instrument. However, this likely underestimates of the frequency of administration of PRO instruments in clinical trials for two reasons: 1) we used an extensive list of search terms in order to capture as many validated PRO instruments as possible, and consequently identified non-relevant articles, and 2) PROs are generally secondary endpoints in clinical trials; as such, they may not be mentioned in the study abstract and commonly are reported in separate publications. Since we did not review the full text of excluded articles, we do not know if the excluded studies were unique clinical trials or secondary publications of identified trials.

There are several limitations to our study that should be noted. First, our review excluded questionnaires measuring adherence because we were only interested in patient-reported measures of treatment effects. However, it should be noted that the HIV-SI/SDM is a component of the ACTG Adherence Questionnaire, a validated instrument developed by the AIDS Clinical Trial Group. Although our review excluded studies which mentioned only adherence and no additional patient-reported measures in the study abstract, based on abstract review we identified two studies which used the ACTG Adherence Questionnaire [34,35]. It is possible that there are additional studies which used the ACTG Adherence Questionnaire as the adherence measure, and therefore also measured HIV symptoms with the HIV-SI/SDM, which were not included in our literature review. Secondly, our review only evaluated studies using validated PRO instruments. However, some studies use study-specific instruments which are based on one or more validated instruments. For example, studies by Santos et al. [36] and Martinez-Picado et al. [37] used modified versions of the MOS-HIV and thus were not fully evaluated in our review. Finally, our review focused on PRO instruments included in prospective clinical trials of NNRTIs. It should be noted that there are clinical research networks, such as the Centers for AIDS Research Network of Integrated Clinical Systems (CNICS) which allow for retrospective review of PROs measured during routine medical visits [38]. PRO instruments used at these clinical sites include the Patient Health Questionnaire (PHQ) for depression and anxiety, HIV-SI for symptom burden, and EQ-5D for HRQL, among others. For example, a study by Kozak et al. [39] used reports from the Patient Health Questionnaire depression scale (PHQ-9) and the Alcohol, Smoking and Substance Involvement Screening Test (ASSIST) to demonstrate that current substance abuse (odds ratio [OR], 2.78; 95\% confidence interval $[\mathrm{CI}], 1.33-5.81$ ) and current depression (OR, 1.93; 95\% CI, 1.12-3.33) were associated with poor antiretroviral adherence in HIV patients. Additional research, including review of NNRTI studies published in non-English languages and retrospective analyses of PROs collected during usual medical care visits, should be conducted and could build on the findings presented here. 
Table 3 PRO instruments identified in trials with NNRTIs

Instrument type and name

Instruments measuring quality of life

Generic

SF-36 (v2)

$\mathrm{SF}-12(\mathrm{~V} 2)$

EORTC QLQ-30

Illness Intrusiveness Rating Scale (IIRS)

Istituto Superiore di Sanità Quality of Life (ISSQoL)

HIV-targeted

Medical Outcomes Study HIV (MOS-HIV)

Functional Assessment of HIV Infection (FAHI)

World Health Organization Quality of Life (WHOQOL)-HIV BREF

Instruments measuring symptoms

General HIV symptoms

HIV Symptom Index (HIV-SI) /AIDS Clinical Trials Group Symptom Distress Module (SDM)

Sleep

Pittsburgh Sleep Quality Index (PSQI)

Epworth Sleep Score (ESS)

Stanford Sleepiness Scale (SSS)

Groningen Sleep Quality Score (GSQS)

Oviedo Sleep Questionnaire (OSQ)

\section{Anxiety (only)}

Hamilton Anxiety Rating Scale (HAM-A)

State-Trait Anxiety Inventory for Adults (STAI)

Depression (only)

Centers for Epidemiological Studies-Depression (CES-D)

Beck Depression Inventory-2nd edition (BDI-II)

Hamilton Depression Rating Scale (HAM-D)

Anxiety and depression (only)

Hospital Anxiety and Depression Scale (HADS)

\section{Anxiety, depression, and stress}

Depression Anxiety and Stress Scale-short version (DASS21)

\section{Psychiatric symptoms}

Positive and Negative Syndrome Scale (PANSS)

Positive and Negative Suicide Ideation (PANSI)

Symptom Checklist-90 (SCL-90) - Somatization Subscale

Body Image Impact scale

Instruments measuring beliefs about medications

Beliefs about Medicines Questionnaire-ART version (BMQ-ART)

${ }^{1} 2$ additional studies used modified versions of the MOS-HIV; ${ }^{2} 2$ additional studies used the ACTG Adherence Questionnaire, which contains the HIV-SI/SDM.

\section{Conclusions}

Review of recently published NNRTI clinical trials suggests a lack of consensus on the optimal PRO instruments to include to measure key domains. Overall, a typical battery of instruments is comprised of a multidimensional measure of HRQL (either HIV-targeted or generic) coupled with one or more symptom measures. Further work is needed to clarify the advantages and disadvantages of using various 
Table 4 PRO results of commonly used instruments

\begin{tabular}{|c|c|c|c|c|c|c|}
\hline $\begin{array}{l}\text { Study } \\
\text { reference }\end{array}$ & Treatment/dosing regimen & Domain & $\begin{array}{l}\text { Baseline score } \\
\text { mean (SD) }\end{array}$ & $\begin{array}{l}\text { Follow-up score } \\
\text { [time, mean] }\end{array}$ & $\begin{array}{l}\text { Effect } \\
\text { size }\end{array}$ & Summary of PRO results \\
\hline \multicolumn{7}{|c|}{ Instrument: Centre for Epidemiologic Studies - Depression Scale (CES-D) } \\
\hline \multirow[t]{2}{*}{$\begin{array}{l}\text { Lake (2012) } \\
\text { [9] }\end{array}$} & $\begin{array}{l}\text { Immediate switch of PI or } \\
\text { NNRTI to RAL (continuing } \\
\text { prior NRTI backbone) }\end{array}$ & Depression & NR & 24 weeks, NR & $\mathrm{N} / \mathrm{A}$ & \multirow{2}{*}{$\begin{array}{l}\text { - The CES-D was administered at } 0,4 \text {, } \\
8,12,18 \text {, and } 24 \text { weeks, but patient- } \\
\text { reported depression scores were not } \\
\text { reported in this study. }\end{array}$} \\
\hline & $\begin{array}{l}\text { Delayed switch (at } 24 \text { weeks) } \\
\text { of PI or NNRTI to RAL } \\
\text { (continuing prior NRTI } \\
\text { backbone) }\end{array}$ & Depression & NR & 24 weeks, NR & $\mathrm{N} / \mathrm{A}$ & \\
\hline \multirow[t]{4}{*}{$\begin{array}{l}\text { Clifford } \\
\text { (2009) [22] }\end{array}$} & ZDV/3TC/EFV & Depression & $12.2(10.5)$ & 184 weeks $^{1}, 10.1^{\mathrm{a}}$ & 0.20 & $\begin{array}{l}\text { - In participants who continued EFV- } \\
\text { based regimens, neuropsychological } \\
\text { performance improvement from } \\
\text { baseline was maintained over } 3 \text { years. }\end{array}$ \\
\hline & ZDV/3TC/ABC & Depression & $11.8(10.5)$ & 184 weeks $^{1}, 10.4$ & 0.13 & $\begin{array}{l}\text { - There was statistically significant } \\
\text { decrease in depression symptoms over } \\
\text { the course of the study with the } \\
\text { median score decline of } 1.0(P=0.03) \text {. }\end{array}$ \\
\hline & Various regimens ( $\pm \mathrm{EFV}$ ) & Depression & $13.3(11.1)$ & 184 weeks $^{1}, 16.6$ & -0.30 & \multirow{2}{*}{$\begin{array}{l}\text { - In the long-term EFV-treated group, } \\
\text { the percent with CES-D scores }>16 \\
\text { declined from } 34.1 \% \text { to } 22.3 \% \text { over the } \\
\text { duration of the study. }\end{array}$} \\
\hline & $\begin{array}{l}\text { ZDV/3TC/ABC initially, then } \\
\text { EFV added }( \pm A B C)\end{array}$ & Depression & $13.8(12.5)$ & 184 weeks $^{1}, 8.6$ & 0.42 & \\
\hline \multirow{4}{*}{$\begin{array}{l}\text { Journot } \\
\text { (2006) [29] }\end{array}$} & PI-based therapy & Depression $^{2}$ & $23 \%$ & 48 weeks, $25 \%$ & N/A & \multirow{3}{*}{$\begin{array}{l}\text { - Proportion of patients with } \\
\text { depression was approximately } 24 \% \text { at } \\
\text { BL and remained stable during the } 48 \\
\text { week follow-up with no difference } \\
\text { between treatment arms, } P=0.65 \text { ). }\end{array}$} \\
\hline & EFV-based therapy & Depression $^{2}$ & $25 \%$ & 48 weeks, $24 \%$ & N/A & \\
\hline & & & & 36 months, $24 \%$ & N/A & \\
\hline & & & & & & $\begin{array}{l}\text { - Patients with a history of depression } \\
\text { experienced depressive symptoms } \\
\text { more frequently than those without } \\
\text { such history ( } 53 \% \text { and } 22 \% \text { at week } 48 \text {, } \\
\text { respectively; } P=0.03 \text { ). }\end{array}$ \\
\hline
\end{tabular}

Instrument: Functional Assessment of HIV Infection (FAHI)

Campo Switch to EFV/3TC/ddl Total Score 130

48 weeks, $134^{\mathrm{a}}$

N/A

FA

- In the overall patient population, FAHI total score increased significantly from BL to week $48(P<0.001)$ and at every other time point; changes in total score were associated with improvements in the physical and emotional well-being domains ( $P<0.001$ for both).

Switch PI to EFV (continuing Total Score 132 prior NRTIs)

48 weeks, $138^{\mathrm{a}} \quad \mathrm{N} / \mathrm{A}$

- No significant between-group differences observed.

$\begin{array}{llll}\text { Cella (2010) } & \text { ETR } 200 \mathrm{mg} \text { twice-daily }^{3} & \text { Total Score } & 121.7(23.7)^{5} \\ \text { [15] } & \text { Placebo }^{3} & \text { Total Score } & 120.9(26.7)^{5}\end{array}$

Boyle (2008) Continue BL ARVs (BID+ $\quad$ Total Score 130.4

[25] dosing)

\section{4 weeks, $127.3^{\mathrm{a}, \mathrm{b}} \quad 0.21$}

24 weeks, $124.0^{\mathrm{a}, \mathrm{b}} \quad 0.1$

- The change in physical well-being, emotional well-being/living with HIV and total scores from BL to Week 24 were statistically different from zero for both groups, with statistically significant greater improvements observed in the ETR group.

48 weeks, NR

- A small improvement (5\% or less) for the emotional well-being and a small reduction ( $9 \%$ or less) for functional and global well-being were observed at some time points in both arms; however, these were not considered clinically relevant, as the effect sizes were small.

- No significant differences observed between arms. 
Table 4 PRO results of commonly used instruments (Continued)

\begin{tabular}{|c|c|c|c|c|c|c|}
\hline \multicolumn{7}{|c|}{ Instrument: HIV Symptom Index / Symptom Distress Module (HIV-SI / SDM) } \\
\hline \multirow{4}{*}{$\begin{array}{l}\text { Hodder } \\
\text { (2010) [19] }\end{array}$} & \multirow[t]{2}{*}{$\mathrm{EFV} / \mathrm{FTC} / \mathrm{TDF}$} & \multirow[t]{2}{*}{ Dizziness } & \multirow[t]{2}{*}{$28 \%$} & 4 weeks, $39 \%$ & N/A & \multirow{4}{*}{$\begin{array}{l}\text { - Simplification from PI-based or NNRTI- } \\
\text { based regimens to EFV/FTC/TDF was } \\
\text { associated with transient worsening or } \\
\text { emergence of dizziness and sustained } \\
\text { improvements in several other HIV- } \\
\text { related symptoms: diarrhea or loose } \\
\text { bowel movements; bloating, pain or gas } \\
\text { in the stomach, changes in body } \\
\text { appearance, and problems having sex. }\end{array}$} \\
\hline & & & & 48 weeks, $28 \%$ & N/A & \\
\hline & \multirow{2}{*}{$\begin{array}{l}\text { Remain on } B L \text { antiretroviral } \\
\text { regimen }\end{array}$} & \multirow[t]{2}{*}{ Dizziness } & \multirow[t]{2}{*}{$27 \%$} & 4 weeks, $25 \%{ }^{\mathrm{b}}$ & N/A & \\
\hline & & & & 48 weeks, $28 \%$ & N/A & \\
\hline \multirow[t]{2}{*}{$\begin{array}{l}\text { Potard } \\
(2010)[21]\end{array}$} & \multirow[t]{2}{*}{ EFV- or NVP-based therapy } & $\begin{array}{l}\text { Symptom } \\
\text { Count }\end{array}$ & $11.9(9.1)$ & 12 months, $9.0^{\mathrm{a}}$ & 0.32 & $\begin{array}{l}\text { - Overall, there was a small } \\
\text { improvement in HIV symptoms at } 1 \\
\text { year (effect size 0.32). }\end{array}$ \\
\hline & & $\begin{array}{l}\text { Symptom } \\
\text { Bother } \\
\text { Count }\end{array}$ & $7.7(5.9)$ & 12 months, $6.0^{\mathrm{a}}$ & 0.29 & $\begin{array}{l}\text { - An initial difference between groups } \\
\text { in mean change in other symptoms, } \\
\text { bothersome symptoms, and other } \\
\text { bothersome symptoms observed at } 1 \\
\text { month was not maintained at months } \\
6 \text { and } 12 \text {. }\end{array}$ \\
\hline $\begin{array}{l}\text { Regnault } \\
\text { (2009) [18] }\end{array}$ & $\begin{array}{l}\text { ZDV/3TC + MVC } 300 \mathrm{mg} \\
\text { twice dailyZDV/3TC + MVC } \\
600 \mathrm{mg} \text { once dailyZDV/3TC + } \\
\text { EFV } 600 \text { mg once daily }\end{array}$ & $\begin{array}{l}\text { Symptom } \\
\text { Count }\end{array}$ & $\begin{array}{l}\text { Mean score ranged } \\
\text { from } \sim 5 \text { (European } \\
\text { Romance group) to } \\
\sim 10 \text { (Bantu group) }\end{array}$ & 96 weeks, NR & N/A & $\begin{array}{l}\text { - This study assessed the cross-cultural } \\
\text { validity of the HIV-SI using pre-ARV } \\
\text { treatment cross-sectional data of the } \\
\text { MERIT trial. }\end{array}$ \\
\hline
\end{tabular}

- Statistically significant differential item functioning between cultural groups was observed for 4 items: fatigue, fevers, anxiety, and headache.

Symptom Mean score ranged 96 weeks, NR N/A • The authors concluded that the Bother from 10.08 (European Count Romance group) to 24.00 (Bantu group) absence of meaningful explanation for statistically significant differences between cultural groups supports the cross-cultural validity of the HIV-SI versions used in the MERIT trial.

\section{(2008) [26] 3TC to once-daily TDF/FTC Count} with EFV

Symptom NR 24 weeks, NR
Bother
Count

- Significant differences were observed in the percentage of patients reporting the absence of the symptom at Week 24 compared to BL for 17 of the 20 items assessed.

- Compared to BL, significantly more patients reported the absence of fatigue, absence of nausea and vomiting, absence of diarrhea, and absence of headache.

\section{Instrument: Medical Outcomes Study HIV health survey (MOS-HIV)}

Jayaweera (2009) [24]

ddl/3TC/EFV once-daily

Total Score

874

96 weeks, 924

$$
\text { d4T/3TC/EFV once-daily }
$$

Lafaurie

(2008) [28]

Pl-containing regimen

PHS

MHS

$56.5(50.0-61.8)^{3}$

$40.2(33.8-45.3)^{3}$

48 weeks, $-1.04^{4}$

48 weeks, $0.00^{4}$

0.24

0.00

EFV/ddl/FTC

PHS

$57.4(51.5-60.4)^{3}$

MHS
48 weeks, $-1.76^{4}$

48 weeks, $1.01^{4}$
0.53

$-0.27$
- The overall MOS-HIV QoL score, which is the sum of all individual MOSHIV scores (range: 0 to 1,100), significantly improved from BL (874) to Week 96 (924; $P<0.05)$.

- The overall MOS-HIV QoL score significantly improved from BL (832) to Week 12 (880; $P<0.05)$.

- The mean change from BL to week 48 in the PCS and MCS were -1.04 and +0.0 in the maintenance arm and -1.76 and +1.01 in the switch arm, respectively ( $P=0.57$ and 0.42$)$.

- Specific items such as physical functioning, social functioning, and emotional functioning remained unchanged in both treatment groups during follow-up. 
Table 4 PRO results of commonly used instruments (Continued)

\begin{tabular}{|c|c|c|c|c|c|c|}
\hline \multirow{6}{*}{$\begin{array}{l}\text { Bucciardini } \\
(2007)[27]\end{array}$} & \multirow[t]{2}{*}{$\mathrm{ddl} / \mathrm{d} 4 \mathrm{~T} / \mathrm{EFV}$} & $\mathrm{PHS}$ & $50(11)$ & 3 years, 54.9 & -0.45 & \multirow{2}{*}{$\begin{array}{l}\text { - Similar results reported for follow-up } \\
\text { at years } 1 \text { and } 2 \text { (data not shown). }\end{array}$} \\
\hline & & MHS & $49(10)$ & 3 years, 49.5 & -0.05 & \\
\hline & \multirow[t]{2}{*}{$\mathrm{ddl} / \mathrm{d} 4 \mathrm{~T} / \mathrm{NFV}$} & PHS & $46(13)$ & 3 years, 50.9 & -0.38 & \multirow{2}{*}{$\begin{array}{l}\text { - During follow-up, an increase of PHS } \\
\text { score was observed in all treatment } \\
\text { arms (NS). }\end{array}$} \\
\hline & & MHS & $48(10)$ & 3 years, 53.5 & -0.55 & \\
\hline & \multirow[t]{2}{*}{$\mathrm{ddl} / \mathrm{d} 4 \mathrm{~T} / \mathrm{EFV} / \mathrm{NFV}$} & PHS & $48(12)$ & 3 years, 50.0 & -0.17 & \multirow{2}{*}{$\begin{array}{l}\text { - The MHS score of both NNRTI- and } \\
\text { PI-based 3-drug regimens showed a } \\
\text { trend toward improvement but } \\
\text { remained substantially unchanged } \\
\text { with the four-drug combination. }\end{array}$} \\
\hline & & MHS & $50(9)$ & 3 years, 53.4 & -0.38 & \\
\hline \multirow[t]{4}{*}{$\begin{array}{l}\text { Portsmouth } \\
\text { (2005) [30] }\end{array}$} & \multirow[t]{2}{*}{$\begin{array}{l}\text { Continue twice-daily regimen } \\
\text { of } d 4 T(I R) / 3 T C / E F V \text { or ZDV/ } \\
3 T C / E F V\end{array}$} & Total Score & NR & 24 weeks, NR & N/A & $\begin{array}{l}\text { - There were no significant differences in } \\
\text { quality of life between the IR and PRC } \\
\text { arms based on overall (sum of } 11 \\
\text { domains) change from BL to week } 24 \text {. }\end{array}$ \\
\hline & & $\begin{array}{l}\text { Cognitive } \\
\text { Function }\end{array}$ & NR & 24 weeks, NR ${ }^{a}$ & N/A & $\begin{array}{l}\text { - Both arms showed significant } \\
\text { improvement in the cognitive function } \\
\text { domain }(P<0.001) \text { during the course } \\
\text { of the study, based on BL cognitive } \\
\text { scores at weeks } 12 \text { and } 24 \text {. }\end{array}$ \\
\hline & \multirow{2}{*}{$\begin{array}{l}\text { Switch to once-daily d4T } \\
\text { (PRC)/3TC/EFV }\end{array}$} & Total Score & NR & 24 weeks, NR & N/A & \multirow{2}{*}{$\begin{array}{l}\text { - Differences between groups were } \\
\text { not observed. }\end{array}$} \\
\hline & & $\begin{array}{l}\text { Cognitive } \\
\text { Function }\end{array}$ & NR & 24 weeks, $N R^{a}$ & $\mathrm{~N} / \mathrm{A}$ & \\
\hline \multirow{4}{*}{$\begin{array}{l}\text { Casado } \\
\text { (2004) [31] }\end{array}$} & \multirow[t]{2}{*}{ ZDV/3TC/NFV } & PHS & $54.16(8.97)$ & 12 months, 52.79 & -0.15 & \multirow{3}{*}{$\begin{array}{l}\text { - In the ZDV/3TC/NVP arm, there were } \\
\text { statistically significant changes in the } \\
\text { PHS score }(P<0.01) \text { and a trend } \\
\text { toward statistically significant change } \\
\text { in the MHS score }(P=0.07) \text {. }\end{array}$} \\
\hline & & MHS & $45.72(11.10)$ & 12 months, 49.20 & 0.31 & \\
\hline & \multirow[t]{2}{*}{ ZDV/3TC/NVP } & $\mathrm{PHS}$ & 50.95 (11.37) & 12 months, $56.73^{a}$ & 0.51 & \\
\hline & & MHS & $43.78(9.92)$ & 12 months, 48.22 & 0.45 & $\begin{array}{l}\text { - There were no statistically significant } \\
\text { changes over time in the ZDV/3TC/NFV } \\
\text { arm in both summary scores. }\end{array}$ \\
\hline \multirow[t]{4}{*}{$\begin{array}{l}\text { Negredo } \\
\text { (2004) [32] }\end{array}$} & \multirow[t]{2}{*}{$\begin{array}{l}\text { Continue twice-daily ARV } \\
\text { therapy (PI- or NNRTI-based) }\end{array}$} & $\begin{array}{l}\text { General } \\
\text { Health }\end{array}$ & NR & NR & $\mathrm{N} / \mathrm{A}$ & \multirow{4}{*}{$\begin{array}{l}\text { - Although quality of life tended to } \\
\text { increase in both groups, no significant } \\
\text { differences were found during the } \\
\text { study in general health and health } \\
\text { transition scales. }\end{array}$} \\
\hline & & $\begin{array}{l}\text { Health } \\
\text { Transition }\end{array}$ & NR & NR & N/A & \\
\hline & \multirow[t]{2}{*}{$\begin{array}{l}\text { Switch to once-daily ddl/ } \\
\text { TDF/NVP }\end{array}$} & $\begin{array}{l}\text { General } \\
\text { Health }\end{array}$ & NR & NR & $\mathrm{N} / \mathrm{A}$ & \\
\hline & & $\begin{array}{l}\text { Health } \\
\text { Transition }\end{array}$ & NR & NR & $\mathrm{N} / \mathrm{A}$ & \\
\hline \multirow{6}{*}{$\begin{array}{l}\text { van Leth } \\
\text { (2004) [33] }\end{array}$} & \multirow[t]{2}{*}{$\mathrm{d} 4 \mathrm{~T} / 3 \mathrm{TC} / \mathrm{EFV}$} & $\mathrm{PHS}$ & 50.5 & 48 weeks, 53.9 & $\mathrm{~N} / \mathrm{A}$ & \multirow{2}{*}{$\begin{array}{l}\text { - } \mathrm{PHS} \text { and MHS BL values were } \\
\text { comparable in all } 3 \text { treatment groups } \\
(P=0.883 \text { and } P=0.937 \text {, respectively). }\end{array}$} \\
\hline & & MHS & 46.9 & 48 weeks, 53.9 & $\mathrm{~N} / \mathrm{A}$ & \\
\hline & \multirow[t]{2}{*}{$\mathrm{d} 4 \mathrm{~T} / 3 \mathrm{TC} / \mathrm{NVP}$} & PHS & 51.0 & 48 weeks, 54.9 & $\mathrm{~N} / \mathrm{A}$ & $\begin{array}{l}\text { - No significant differences between } \\
\text { the } 3 \text { treatment groups in increases in } \\
\text { dimension scores. }\end{array}$ \\
\hline & & MHS & 46.7 & 48 weeks, 52.8 & $\mathrm{~N} / \mathrm{A}$ & \multirow{3}{*}{$\begin{array}{l}\text { - After adjusting for all significantly } \\
\text { associated variables, the increase of } \\
\text { PHS was } 4.6 \text { for NVP, } 4.8 \text { for EFV and } \\
3.8 \text { for NVP + EFV }(P=0.790) \text {; the } \\
\text { adjusted increase of MHS was } 6.1,7.3 \\
\text { and 3.8, respectively ( } P=0.093) \text {. }\end{array}$} \\
\hline & \multirow[t]{2}{*}{$\mathrm{d} 4 \mathrm{~T} / 3 \mathrm{TC} / \mathrm{EFV} / \mathrm{NVP}$} & PHS & 50.9 & 48 weeks, 53.8 & N/A & \\
\hline & & MHS & 47.1 & 48 weeks, 51.0 & $\mathrm{~N} / \mathrm{A}$ & \\
\hline
\end{tabular}

Abbreviations: 3TC lamivudine, ABC abacavir, ARV antiretroviral, AZT zidovudine, BL baseline, CF cognitive functioning, d4T stavudine, ddl didanosine, DRV/r darunavir/ritonavir, EFV efavirenz, ENF enfuvirtide, EWB emotional well-being, ETR etravirine, FGWB functional global well-being, FTC emtricitabine, HAART highlyactive antiretroviral therapy, IQR interquartile range, IR immediate release, MCS mental component score, MHS mental health summary, N/A not available, NFV nelfinavir, NNRTI non-nucleoside reverse transcriptase inhibitor, NRTI nucleoside/nucleotide reverse transcriptase inhibitor, NS not significant, NVP nevirapine, PCS physical component score, PHS physical health summary, PI protease inhibitor, PRC prolonged-release capsule, PRO patient-reported outcome, PWB physical well-being, SD standard deviation, SWB social well-being, TDF tenofovir, ZDV zidovudine.

${ }^{1} 184$ weeks, or study discontinuation; ${ }^{2}$ Score $\geq 17$ for men and $\geq 23$ for women; ${ }^{3}$ Median (IQR); ${ }^{4}$ Mean change; ${ }^{5}$ Standard deviation estimated from IQR.

${ }^{a}$ Significant change over time $(P<0.05)$; ${ }^{b}$ Significant change between groups $(P<0.05)$. 
instruments to measure the relevant constructs and to identify the most useful batteries of instruments. Furthermore, new instruments may need to be developed to meet future research needs.

\section{Additional file}

\section{Additional file 1: Table A Search terms for identifying clinical} studies of NNRTIs with PRO instruments.

\section{Competing interests}

$\mathrm{KAH}$ and CLP are employees of UBC and GH is an employee of Evidera, both of which received funding for this research from Pfizer. SH and MT are employees of and have equity ownership in Pfizer. AK was an employee of Pfizer at the time the study was conducted. KNS and AWW received funding for this research from Pfizer.

\section{Authors' contributions}

$\mathrm{KAH}$ and $\mathrm{GH}$ participated in the study conception and design, acquisition of data, data analysis and interpretation, and manuscript writing. KNS, SH, MT, $C L P$, and AWW participated in the study conception and design, data interpretation, and manuscript writing. AK participated in the data interpretation and manuscript writing. All authors read and approved the final manuscript.

\section{Author details}

'Medical University of South Carolina, 171 Ashley Avenue, Charleston, SC 29425, USA. ${ }^{2}$ UBC: An Express Scripts Company, 185 Dorval Ave, Suite 500, Dorval, QC H9S 5J9, Canada. ${ }^{3}$ Evidera, 7101 Wisconsin Avenue, Suite 600, Bethesda, MD 20814, USA. ${ }^{4}$ Pfizer Inc., 558 Eastern Point Road, Groton, CT 06340, USA. ${ }^{5}$ Pharmerit, 4350 East West Highway, Suite 430, Bethesda, MD 20814, USA. ${ }^{6}$ UBC: An Express Scripts Company, 430 Bedford Street, Lexington, MA 02420, USA. ${ }^{7} J o h n s$ Hopkins Bloomberg School of Public Health, 615 North Wolfe Street, Baltimore, MD 21205, USA.

Received: 8 November 2012 Accepted: 5 September 2013 Published: 3 October 2013

\section{References}

1. Clumeck N, Pozniak A, Raffi F: European AIDS Clinical Society (EACS) guidelines for the clinical management and treatment of HIV-infected adults. HIV Med 2008, 9(2):65-71.

2. Hammer SM, Eron JJ Jr, Reiss P, Schooley RT, Thompson MA, Walmsley S, Cahn P, Fischl MA, Gatell JM, Hirsch MS, Jacobsen DM, Montaner JS, Richman DD, Yeni PG, Volberding PA: Antiretroviral treatment of adult HIV infection: 2008 recommendations of the International AIDS Society-USA panel. JAMA 2008, 300(5):555-570.

3. DHHS Panel on Antiretroviral Guidelines for Adults and Adolescents: Guidelines for the use of antiretroviral agents in HIV-1-infected adults and adolescents. Department of Health and Human Services; 2011:1-166. http://www.aidsinfo.nih.gov/ContentFiles/AdultandAdolescentGL.pdf.

4. Food and Drug Administration: Guidance for industry on patient-reported outcome measures: use in medical product development to support labeling claims. Fed Regist 2009, 74(235):65132-65133.

5. DHHS Panel on Antiretroviral Guidelines for Adults and Adolescents: Guidelines for the use of antiretroviral agents in HIV-1-infected adults and adolescents. Department of Health and Human Services; 2008:1-139. http:// www.aidsinfo.nih.gov/ContentFiles/AdultandAdolescentGL.pdf.

6.1 European AIDS Clinical Society (EACS): Guidelines for the clinical management and treatment of HIV infected adults in Europe. Version 6.1 EACS; 2012. http://www.eacsociety.org/Portals/0/files/pdf\%20files/ EacsGuidelines-v6.1-2edition.pdf.

7. Dabaghzadeh F, Ghaeli P, Khalili H, Alimadadi A, Jafari S, Akhondzadeh S, Khazaeipour Z: Cyproheptadine for prevention of neuropsychiatric adverse effects of efavirenz: a randomized clinical trial. AIDS Patient Care STDS 2013, 27(3):146-154.

8. Bucciardini R, D'Ettorre G, Baroncelli S, Ceccarelli G, Parruti G, Weimer LE, Fragola V, Galluzzo CM, Pirillo MF, Lucattini S, Bellagamba R, Francisci D,
Ladisa N, Degli Antoni A, Guaraldi G, Manconi PE, Vullo V, Preziosi R, Cirioni O, Verucchi G, Floridia M: Virological failure at one year in triple-class experienced patients switching to raltegravir-based regimens is not predicted by baseline factors. Int J STD AIDS 2012, 23(7):459-463.

9. Lake JE, McComsey GA, Hulgan TM, Wanke CA, Mangili A, Walmsley SL, Boger MS, Turner RR, McCreath HE, Currier JS: A randomized trial of Raltegravir replacement for protease inhibitor or non-nucleoside reverse transcriptase inhibitor in HIV-infected women with lipohypertrophy. AIDS Patient Care STDS 2012, 26(9):532-540.

10. Mosam A, Shaik F, Uldrick TS, Esterhuizen T, Friedland GH, Scadden DT, Aboobaker J, Coovadia HM: A randomized controlled trial of highly active antiretroviral therapy versus highly active antiretroviral therapy and chemotherapy in therapy-naive patients with HIV-associated Kaposi sarcoma in South Africa. J Acquir Immune Defic Syndr 2012, 60(2):150-157.

11. Cooper V, Moyle GJ, Fisher M, Reilly G, Ewan J, Liu HC, Horne R: Beliefs about antiretroviral therapy, treatment adherence and quality of life in a 48-week randomised study of continuation of zidovudine/lamivudine or switch to tenofovir DF/emtricitabine, each with efavirenz. AIDS Care 2011, 23(6):705-713.

12. Nguyen A, Calmy A, Delhumeau C, Mercier I, Cavassini M, Mello AF, Elzi L, Rauch A, Bernasconi E, Schmid P, Hirschel B: A randomized cross-over study to compare raltegravir and efavirenz (SWITCH-ER study). AIDS 2011, 25(12):1481-1487.

13. Nguyen A, Calmy A, Delhumeau C, Mercier IK, Cavassini M, Fayet-Mello A, Elzi L, Genne D, Rauch A, Bernasconi E, Hirschel B: A randomized crossover study to compare efavirenz and etravirine treatment. AIDS 2011, 25(1):57-63.

14. Campo RE, Cohen C, Grimm K, Shangguan T, Maa J, Seekins D: Switch from protease inhibitor- to efavirenz-based antiretroviral therapy improves quality of life, treatment satisfaction and adherence with low rates of virological failure in virologically suppressed patients. Int J STD AIDS 2010, 21(3):166-171.

15. Cella D, Gilet H, Viala-Danten M, Peeters K, Dubois D, Martin S: Effects of etravirine versus placebo on health-related quality of life in treatmentexperienced HIV patients as measured by the functional assessment of human immunodeficiency virus infection (FAHI) questionnaire in the DUET trials. HIV Clin Trials 2010, 11(1):18-27.

16. Cooper V, Horne R, Gellaitry G, Vrijens B, Lange AC, Fisher M, White D: The impact of once-nightly versus twice-daily dosing and baseline beliefs about HAART on adherence to efavirenz-based HAART over 48 weeks: the NOCTE study. J Acquir Immune Defic Syndr 2010, 53(3):369-377.

17. Cooper DA, Heera J, Goodrich J, Tawadrous M, Saag M, Dejesus E, Clumeck N, Walmsley S, Ting N, Coakley E, Reeves JD, Reyes-Teran G, Westby M, Van Der Ryst E, Ive P, Mohapi L, Mingrone H, Horban A, Hackman F, Sullivan J, Mayer H: Maraviroc versus efavirenz, both in combination with zidovudine-lamivudine, for the treatment of antiretroviral-naive subjects with CCR5-tropic HIV-1 infection. J Infect Dis 2010, 201(6):803-813.

18. Regnault A, Marfatia S, Louie M, Mear I, Meunier J, Viala-Danten M: Satisfactory cross-cultural validity of the ACTG symptom distress module in HIV-1infected antiretroviral-naive patients. Clinical trials 2009, 6(6):574-584.

19. Hodder SL, Mounzer K, Dejesus E, Ebrahimi R, Grimm K, Esker S, Ecker J, Farajallah A, Flaherty JF: Patient-reported outcomes in virologically suppressed, HIV-1-Infected subjects after switching to a simplified, single-tablet regimen of efavirenz, emtricitabine, and tenofovir DF. AIDS Patient Care STDS 2010, 24(2):87-96.

20. DeJesus E, Young B, Morales-Ramirez JO, Sloan L, Ward DJ, Flaherty JF, Ebrahimi R, Maa JF, Reilly K, Ecker J, McColl D, Seekins D, Farajallah A: Simplification of antiretroviral therapy to a single-tablet regimen consisting of efavirenz, emtricitabine, and tenofovir disoproxil fumarate versus unmodified antiretroviral therapy in virologically suppressed HIV1-infected patients. J Acquir Immune Defic Syndr 2009, 51(2):163-174.

21. Potard V, Chassany O, Lavignon M, Costagliola D, Spire B: Better health-related quality of life after switching from a virologically effective regimen to a regimen containing efavirenz or nevirapine. AIDS Care 2010, 22(1):54-61.

22. Clifford DB, Evans S, Yang Y, Acosta EP, Ribaudo H, Gulick RM: Long-term impact of efavirenz on neuropsychological performance and symptoms in HIV-infected individuals (ACTG 5097s). HIV Clin Trials 2009, 10(6):343-355.

23. Gutierrez-Valencia A, Viciana P, Palacios R, Ruiz-Valderas R, Lozano F, Terron A, Rivero A, Lopez-Cortes LF: Stepped-dose versus full-dose efavirenz for HIV infection and neuropsychiatric adverse events: a randomized trial. Ann Intern Med 2009, 151(3):149-156. 
24. Jayaweera D, Dejesus E, Nguyen KL, Grimm K, Butcher D, Seekins DW: Virologic suppression, treatment adherence, and improved quality of life on a once-daily efavirenz-based regimen in treatment-Naive HIV-1infected patients over 96 weeks. HIV Clin Trials 2009, 10(6):375-384

25. Boyle BA, Jayaweera D, Witt MD, Grimm K, Maa JF, Seekins DW: Randomization to once-daily stavudine extended release/lamivudine/ efavirenz versus a more frequent regimen improves adherence while maintaining viral suppression. HIV Clin Trials 2008, 9(3):164-176.

26. DeJesus E, Ruane P, McDonald C, Garcia F, Sharma S, Corales R, Ravishankar J, Khanlou H, Shamblaw D, Ecker J, Ebrahimi R, Flaherty J: Impact of switching virologically suppressed, HIV-1-infected patients from twice-daily fixed-dose zidovudine/lamivudine to once-daily fixed-dose tenofovir disoproxil fumarate/emtricitabine. HIV Clin Trials 2008, 9(2):103-114.

27. Bucciardini R, Fragola V, Massella M, Polizzi C, Mirra M, Goodall R, Carey D, Hudson F, Zajdenverg R, Floridia M: Health-related quality of life outcomes in HIV-infected patients starting different combination regimens in a randomized multinational trial: the INITIO-QoL substudy. AIDS Res Hum Retroviruses 2007, 23(10):1215-1222.

28. Lafaurie M, Collin F, Bentata M, Garre M, Leport C, Levy Y, Goujard C, Chene G, Molina JM: Switch from zidovudine- to non-zidovudine-containing regimens is associated with modest haematological improvement and no obvious clinical benefit: a substudy of the ANRS 099 ALIZE trial. J Antimicrob Chemother 2008, 62(5):1122-1129.

29. Journot V, Chene G, De Castro N, Rancinan C, Cassuto JP, Allard C, Vilde JL, Sobel A, Garre M, Molina JM: Use of efavirenz is not associated with a higher risk of depressive disorders: a substudy of the randomized clinical trial ALIZE-ANRS 099. Clin Infect Dis 2006, 42(12):1790-1799.

30. Portsmouth SD, Osorio J, McCormick K, Gazzard BG, Moyle GJ: Better maintained adherence on switching from twice-daily to once-daily therapy for HIV: a 24-week randomized trial of treatment simplification using stavudine prolonged-release capsules. HIV Med 2005, 6(3):185-190.

31. Casado A, Badia X, Consiglio E, Ferrer E, Gonzalez A, Pedrol E, Gatell JM, Azuaje C, Llibre JM, Aranda M, Barrufet P, Martinez-Lacasa J, Podzamczer D, Team CS: Health-related quality of life in HIV-infected naive patients treated with nelfinavir or nevirapine associated with ZDV/3TC (the COMBINE-QoL substudy). HIV Clin Trials 2004, 5(3):132-139.

32. Negredo E, Molto J, Munoz-Moreno JA, Pedrol E, Ribera E, Viciana P, Galindos MJ, Miralles C, Burger D, Rodriguez Fumaz C, Puig J, Gel S, Rodriguez E, Videla S, Ruiz L, Clotet B: Safety and efficacy of once-daily didanosine, tenofovir and nevirapine as a simplification antiretroviral approach. Antiviral therapy 2004, 9(3):335-342.

33. van Leth F, Conway B, Laplume H, Martin D, Fisher M, Jelaska A, Wit FW, Lange JM, group NNs: Quality of life in patients treated with first-line antiretroviral therapy containing nevirapine and/or efavirenz. Antiviral therapy 2004, 9(5):721-728.

34. Kallianpur AR, Hulgan T, Canter JA, Ritchie MD, Haines JL, Robbins GK, Shafer RW, Clifford DB, Haas DW: Hemochromatosis (HFE) gene mutations and peripheral neuropathy during antiretroviral therapy. AIDS 2006 20(11):1503-1513.

35. Maggiolo F, Ravasio L, Ripamonti D, Gregis G, Quinzan G, Arici C, Airoldi M, Suter F: Similar adherence rates favor different virologic outcomes for patients treated with nonnucleoside analogues or protease inhibitors. Clin Infect Dis 2005, 40(1):158-163.

36. Santos J, Palacios R, Lopez M, Galvez MC, Lozano F, de la Torre J, Rios MJ, Lopez-Cortes LF, Rivero A, Torres-Tortosa M, Grupo Andaluz para el Estudio de las Enfermedades I: Simplicity and efficacy of a once-daily antiretroviral regimen with didanosine, lamivudine, and efavirenz in naive patients: the VESD study. HIV Clin Trials 2005, 6(6):320-328.

37. Martinez-Picado J, Negredo E, Ruiz L, Shintani A, Fumaz CR, Zala C, Domingo P, Vilaro J, Llibre JM, Viciana P, Hertogs K, Boucher C, D'Aquila RT, Clotet B, Team SS: Alternation of antiretroviral drug regimens for HIV infection. A randomized, controlled trial. Ann Intern Med 2003, 139(2):81-89.
38. Centers for AIDS Research (CFAR) Network of Integrated Clinical Systems (CNICS): CNICS Data Elements http://www.uab.edu/cnics/data-core/cnicsdata-elements.

39. Kozak MS, Mugavero MJ, Ye J, Aban I, Lawrence ST, Nevin CR, Raper JL, McCullumsmith C, Schumacher JE, Crane HM, Kitahata MM, Saag MS, Willig $\mathrm{JH}$ : Patient reported outcomes in routine care: advancing data capture for HIV cohort research. Clin Infect Dis 2012, 54(1):141-147.

doi:10.1186/1477-7525-11-164

Cite this article as: Simpson et al:: Patient reported outcome instruments used in clinical trials of HIV-infected adults on NNRTI-based therapy: a 10-year review. Health and Quality of Life Outcomes 2013 11:164.

\section{Submit your next manuscript to BioMed Central and take full advantage of:}

- Convenient online submission

- Thorough peer review

- No space constraints or color figure charges

- Immediate publication on acceptance

- Inclusion in PubMed, CAS, Scopus and Google Scholar

- Research which is freely available for redistribution 